\title{
大胸筋皮弁の血行形態に関する研究
}

\author{
石川好美
}

\section{Study on the vascular pattern of the pectoralis major musculocutaneous flap}

\section{Yoshimi IsHIKawa}

\begin{abstract}
The pectoralis major musculocutaneous flap (PMMC-flap) has been used for the immediate reconstruction of defects in the head and neck region. This technique is highly valued because it can transplant a large amount of well-vascularized tissue, but its vascular pattern seems to have been characterized by a simple axial pattern without adequate investigation.
\end{abstract}

Recently, the vascular anatomy has been clarified gradually as many authors have reported on it in detail. The purpose of this study was to define the vascular pattern of the PMMCflap by dye injection, angiography and cadaver dissection.

Materials and methods:

Dye injection: Fresh cadavers ( 3 males, 2 females), were used and different color inks werc injected in to the internal thoracic artery and thoracoacrominal artery. Then the colored skin areas on the chest were observed and recorded. Angiography: Fresh cadavers (3 males, 7 females) were also used into which a contrast medium was infused via the femoral artery, and the pectoralis major muscle and overlying skin with adjacent vessels were resected. After taking X-ray photographs and making the angiograms, the vascular patterns in the muscle and cutaneous layer were analysed. Subsequently the PMMC-flap on the cadavers was evaluated and the vascular pattern was analysed from the angiograms.

Cadaver dissection: The vascular anatomy was studicd by cadaver dissection.

Results :

1) The pectoralis major muscle and the overlying skin were found to receive their blood supply from separate blood vessels.

2) The musculocutaneous perforators directly airisng from the dominant artery appeared in certain limited areas only and not observed in the area where the skin island is usually designed.

3) The blood supply of the PMMC-flap was supported by a communicating circulatory system from the muscle to cutaneous layer, which was formed by the pectoral branch anastomosing with the anterior perforators in the muscle and fascial laycr.

4) It scems that the vascular pattern of the PMMC-flap is not of axial pattern directly sustained by musculocutancous perforators arising from the pectoral branch but is of extended axial pattern which is spreaded in three dimensions by anastomosis to adjacent vessels.

5) The concept of this vascular pattern is very important and the author thinks that with

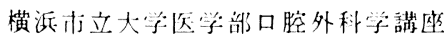

（主任：藤田浄秀教授）

Department of Oral and Maxillofacial Surgery,
School of Medicine, Yokohama City University (Chief: Prof. Kiyohide Fujita)

受付日：平成元年10月31日 
this knowledge we can reduce the risk of partial and/or marginal necrosis in the skin island on the PMMC-flap.

Key words: pectoralis major musculocutaneous flap (大胸筋皮弁), vascular pattern (血行形 態), anatomical study (解剖学的研究)

緒

頭頸部領域における再建外科の進歩はめざすしく， 舌, 口底, 頓粘膜などの広範切除に伴ら大きな組織欠損 る筋肉と皮盛の複合組織を有茥皮弁あるいは遊離皮弁に することにより一期的再建が可能となっている1 これ までに多くの歨任性笳肉を利用した筋皮弁が考案され臨 朱に応用されてきたが2 そ)，その基盤となるのは笳肉血 行と皮屑血行に関する詳細な血管解剖であることはいら までもない，そして臨床的に安全かつ合理的な筋皮弁を 作成するためには，笳肉内の栄養血管から皮膚に至る循 環経路と，その支配領域を知ることが重要である。

代表的な㳙皮弁の一つである大胸筋皮弁は1979年 Ari$\mathrm{yan}^{5)}$ がその原法を発表して以来，頭頸部悪性腫㻛切除 後の大きな組織欠損を再建する方法として頻用され，そ の有用性は高く評価されている の血行形態は，胸肩峰動脈胸㬳枝を栄養血管とし，上部 皮虚はそれから分枝した筋肉一皮䇠買通枝 (musculocutaneous perforator) に上って支持される公義の axial pattern flap と考えられた包。これを支持する見解とし て Freeman $5^{10)}$ の血管造影と解剖所見があり，それに よると大胸筋上の皮华には胸筋枝から垂直方向に立ら上 がる筋肉一皮价貫通枝が豊富に存在するため血行的に安 全であるとしている，しかし，その後多くの臨床応用の 結果が報告されると吕,12), 皮島部の部分壊死や辺縁壊死 が少なくなく，その原因が必ずしも手術手技や移植床の 問題だけとはいえず，大胸笳皮弁の血行形態上の問題， 珎に血管の分布様式や支配領域に関寸る検討が必要とな った，1981年 Nakajima ら ${ }^{13}$ は，Prostagradin-E いて体幹部の皮后血行の支配領域を示し，1984年 Reid ら ${ }^{14}$ は, 色素注入法と血管造影法に上り胸肩蜂動脈の固 有支配領域を示した，両者の結果とも大胸筋とその上部 皮间間には異なる支配血管が存任し，大胸筋皮并の栄盖 血管である胸䍉枝が直接支配する領域は限られた部分に すぎないとしたことから，根本的に大胸筋皮弁の血行形 態を検討する必要があると思われる。

今回著者は, 大胸筋皮弁の血行形態を明らかにするこ とを目的とし，新鮮屁体を用いた色素注入法と血管造影 法ならびにその解剖所見から検討したので報告する。

\section{研究 方 法}

色素注入法：男性 3 例，女性 2 例の新鮮尼体を用い， 鎖骨下部より内胸動脈および胸局蜂動脈へ選択的にカ二 ニーレを揮入し，それぞれ異なる色の色素 (Indian ink) $40 \mathrm{ml}$ を手压にて注入しながら皮成の染色状態を経時的 写真撮影にて記録, 観察した。

血管造影法：男性 3 例, 女性 7 例の新鮮屍体に, 大腿 動脈より朱色に着色した酸化鉛を含む造影剤を高压注入 しホルマリン固定した後, 大胸筋とその上部の前胸部皮 凰に胸肩蜂動脈, 内胸動脈, 外側胸動脈などの関連血管 を含むょうに切除し検体とした。この検体をエックス線 撮影することにより全体の血管造影写真を作成した．エ ックス線発生装珇は YAMATO Type No. 7 (HIDA DENKI 工業製) で，フィルムは Kodak X-Omat TL を使用した，撮影条件は，管球とフィルム間距離を60 $\mathrm{cm}$ とし， $65 \mathrm{kVp} 20 \mathrm{~mA} 5 \mathrm{sec}$ で撮影した後, 自動現像 機にて現像した。

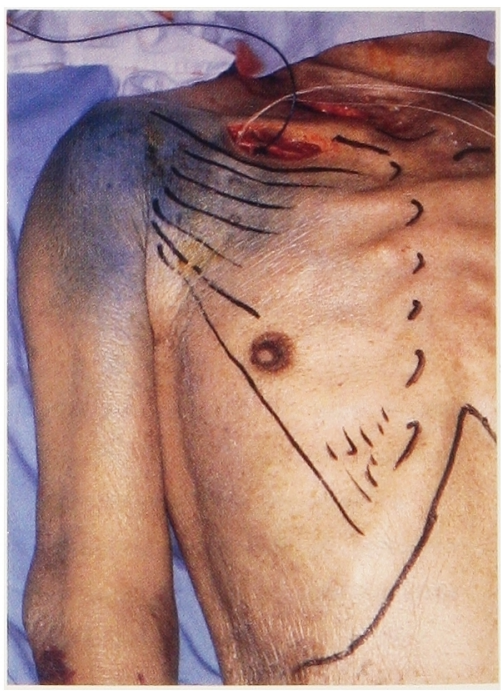

写真 1 色素注入による皮店染色所 見 (胸肩峰動脈胸筇枝, 女 性)

青色の色素を注入すると三角筋上か ら俶简部の皮庙化染色域を認める。 


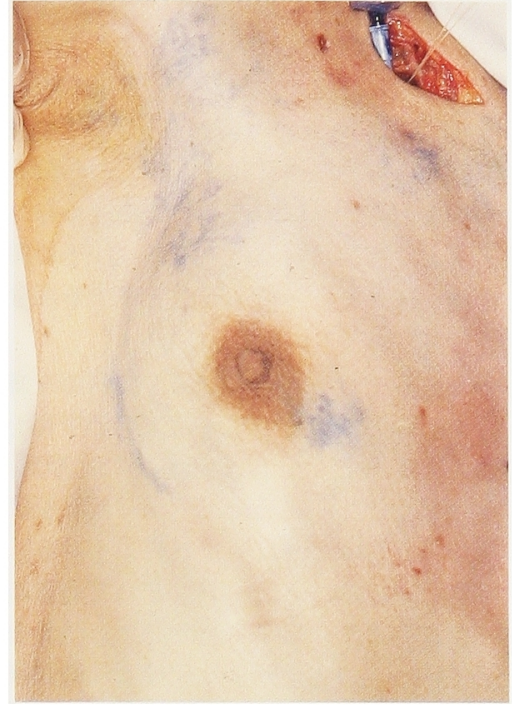

写直 2 色素注入による皮膚染色所見 （胸肩峰動脈胸筋枝，女性）

大胸筋外側縁之乳頭の内側に青色の染 色域を認める。

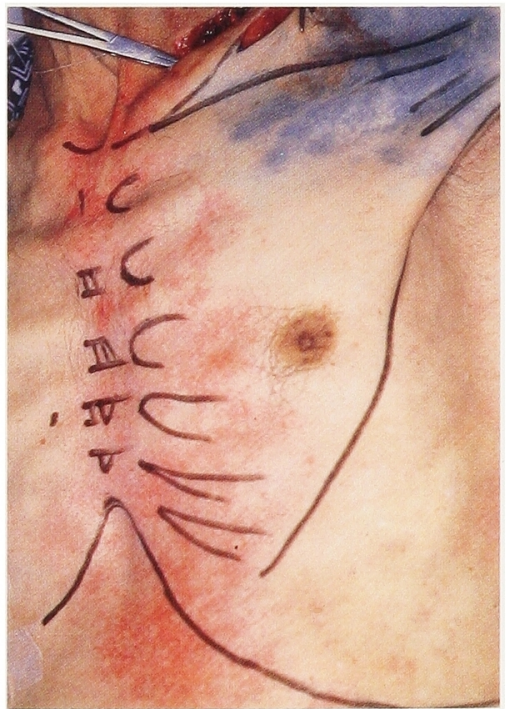

写真 3 色素注入に上る皮底染色所 胃(内胸動脈，男性）

赤色の色素を $20 \mathrm{~m} l$ 注入した時の皮 虚染色範囲を示し，胸骨側緣から腹 直筋上に带状の染色域を認める。

次に検体を筋層と皮成皮下組織層に分離し，同様の方 法でおのおのの微小血管造影写真を作成し血行形態を分 析した。

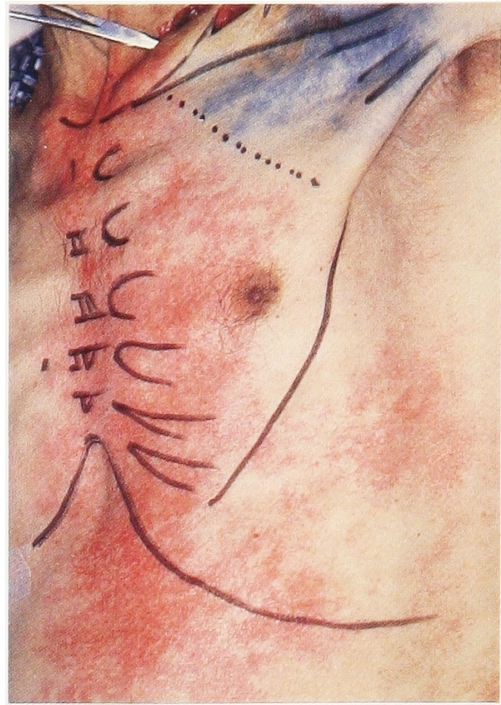

写真 4 色素注入による皮層染色所見 （内胸動脈，男性）

赤色の色素を $40 \mathrm{ml}$ 注入した時の皮層 染色範围の変化を示す，青色の染色域 との境界は点線部で分けられ，外側胸動 脈の領域は染色されずに皮有色を呈している.

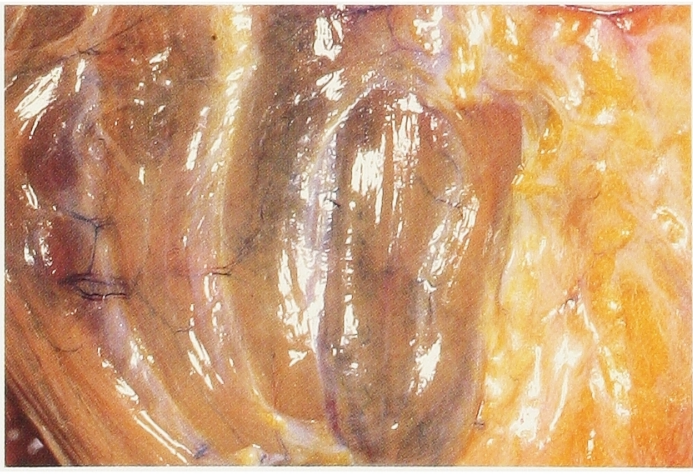

写真 5 色沙注入後の解剖所見

胸肩峰動脈胸筋枝より注入された青色の色素炎入れ た血管が大胸筋内也竻膜表耐に認められる。

さらに大胸筋皮我自体の血行形態を钼察するため，起

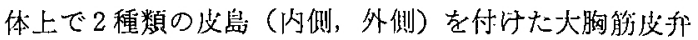
を作成し，同様の方法で微小业管造影写真を俳成し㖹肉

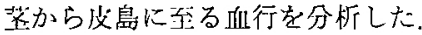

血管解剖：色菜注入法ならびに血管造影法に用いた成 体を解剖し，血管の走行や分杪様式について肉腿的観䋈 を行った。 


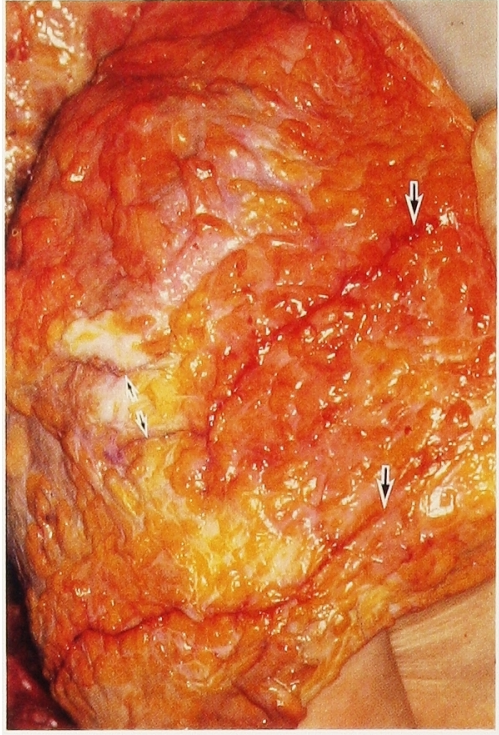

写可 6 色素注入後の解剖所見 大筑筋上の皮虚を正中㑡上り管膜上 で举上すると大知印で示す赤い色素 を入れた内胸動脈の貫通枝と，大胸 筋の外側影に小矢印で示す青色の色 素を入れた血管を認める。

\section{結}

\section{果}

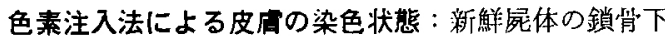
部からのアプローチにより胸肩峰動脈を露出し，胸筋枝 を確認後動脈内人選択的にカーューレを插入し，青色の 色素を $40 \mathrm{~m} l$ 手代にて注入した，染色範囲は三角朌胸胼 满周迅から三角筋上の皮膚と，大胸筋上では脑简部に限 られ，その他の大胸筇上の皮阅はほとんど染色されなか った（写真1），しかし 5 例中 2 例では，前腋窝線上の 大胸筇外側縁に沿った皮消亡乳頭周囲に孤立した狭い染 色域が認められた（写真 2).

胸鎖関節上部よりのアプローチにより内胸動脈へ選択 的にカニューレを㨂入し，赩の色素を $20 \mathrm{ml}$ 手压にて 注入すると胸骨外㒋縁の肋間部之腹直筋起始部上の皮施 に涌出るような染色域が出現し（写真了）, 注人量の 增加とともに侧方に桩大し， $40 \mathrm{~m} l$ 注入終了時には反対

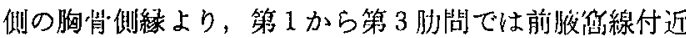
までが染色され，解 4 肋間以降では倒胸部から腹直筋上

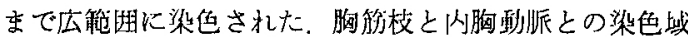

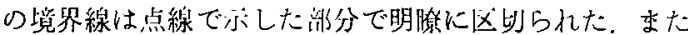
外倒胸動脈の領域は染色されず残された（写真 4).

色素注入後の解剖所見：色奖注入後に大脢効とその上 部皮悄を切除し染色状態を観察すると，大胸觔の新面に は青色の色素が入った胸筋校の主幹が㴓められ，管膜や
筋肉内の枝にも青色の色素が認められた，大胸筋表面で は胸助起始部付近の血管内には内胸動脈上り注入された 赤色の色素が認められ，その他の筋膜や筋肉内の血管内 には青色の色素が認められた（写真 5 ），皮下組織層で は，矢印で示した内胸動脈の貫通枝とそこから分枝した 枝で形成される皮下血管網浾色の色素が認められた。 そ乙て鎖管下部之側胸部の筋膜の一部《は，小矢印で示 した赤色と青色の色素の入った血管が混在する部分も認 められた（写直 6 )。

前胸部全体の血管造影所見：大胸筋之前胸部皮庴に関 連血管を付けて切除した検体の微小血管造影写真を作成 し，前胸部に打ける血行の分布を観察した（写直 7). 鎖肖・下動脈から分枝した内胸動脈が，胸骨側緣を縦走し ながら第1から第 5 肋間より貫通枝（P 1 ～P 5) を出 している，第 6 助間以降は，前助間枝として助骨に沿っ て外側㹸向い，背側上り分布する肋間動脈と肋骨を囲む

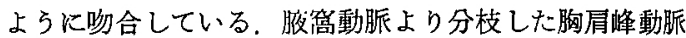
胸筋枝は，上外側から下内側に向って数本の枝が樹枝状 に分れて分布している．外側胸動脈は胸肩峰動脈の遠心 側で腋䆚動脈より分枝し，下方に向い側胸部に分布して いる.

大胸筋の血管造影所見：切除検体より大胸筋のみを分 離し，その徾小血管造影写真から血行形態を観察した。 腋窝動脈の枝である胸肩峰動脈は，動脈幹として鎖骨胸 静筋膜を穿通した後，胸管枝，三角筋枝，鎖骨枝，局峰 枝の 4 本の動脈に分枝するとされている15》．大胸脇の栄 盖血管である胸筋枝は大胸筋の鎖骨起始部の深層より筋 肉下面の筇膜内に入り，筋肉内で鎖骨部に分布寸る枝と 胸胁部に分布する枝に分れる．鎖骨部に分布する枝から は，Kaplan $5^{16)}$ が初めて報告した鎖骨下部より腋窩部 の皮何に分布する 2 本の訜肉一皮留貫通枝が 確認され た (写真 8 ). 胸胁部への枝は大胸筋 の停止側約 $2 / 3$ に 分布し， 最初鎖骨部の筋束に 直交するように下方へ向 い，樹枝状あるいは螺旋状に走行しながら徐々に筋束に 沿うように正中側へ向う。そして大胸終の外側縁では， 矢印で示すように最外側を走行する枝の一部が，大胸筋 の外僛筋膜を穿通して侧胸部の皮下組織に移行している るのと（写直 9)，逆に外側胸動脈の枝が 大胸筋の外侧 より入り，胸皏枝と吻合するものとがある（写真 8 ， 10).

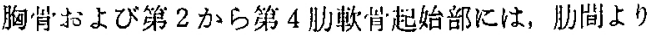
出現する以胸動脈の㙋通校の筋枝（Pm 1 Pm 5) 怔出 現し，大胸筋起始侧約 $1 / 3$ に分布している。買通枝の皮

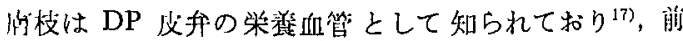
胸部皮下組織化分们する皮泊支配血管 (direct-cutaneous artery）とされているが，その主幹が胸郭内面の内胸勔 脈から皮下組織層に立ら上がるまでに，胸骨や肋少の肖 膜，ならびに肋間筋や大胸筋への枝を出す，大胸筋への 螈枝は，主幹が大胸筋を買通する途中から分枝し筋束に 


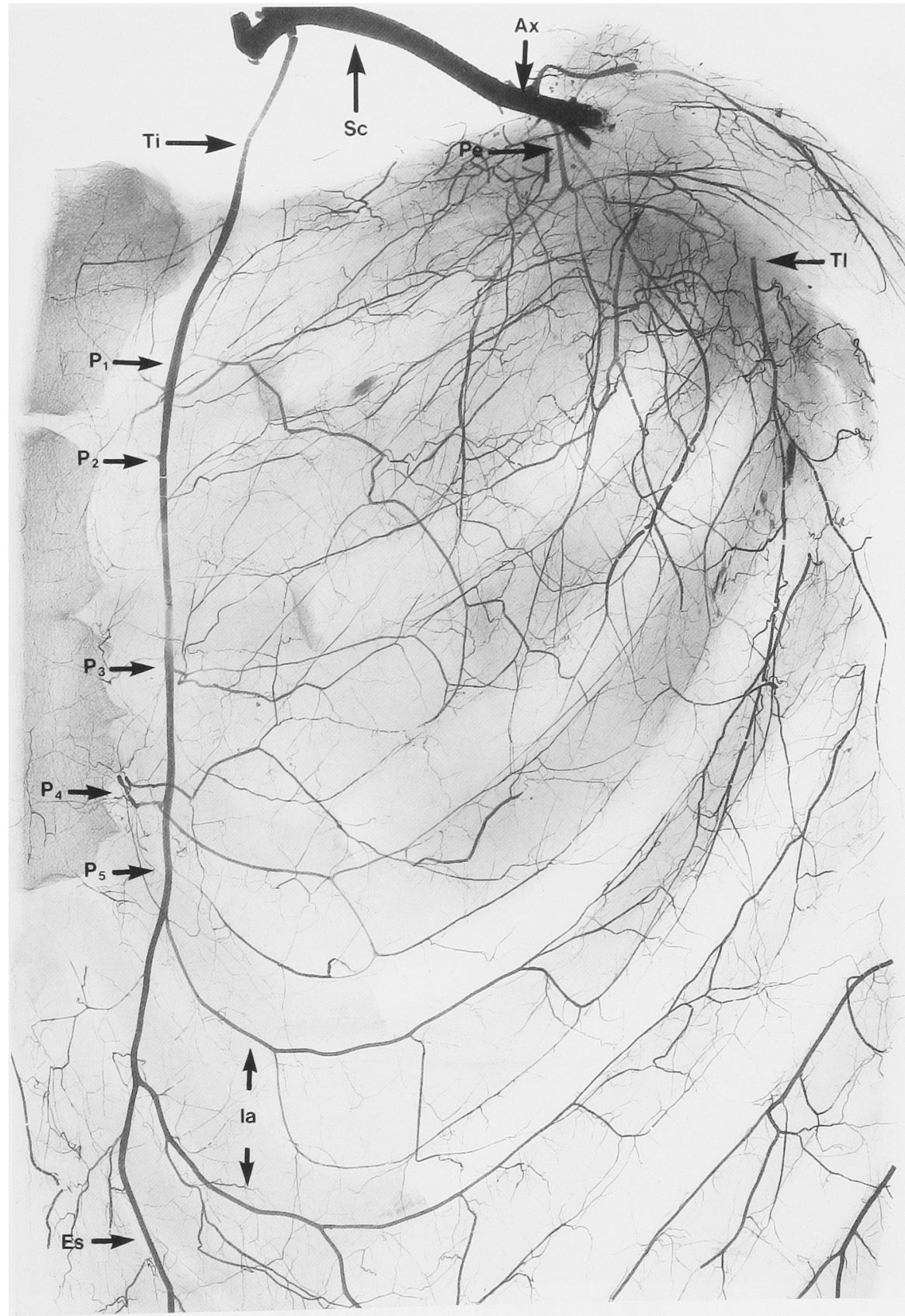

写真 7 前胸部全体の請小血管造影写真

前胸部に分布する丘行を示す。

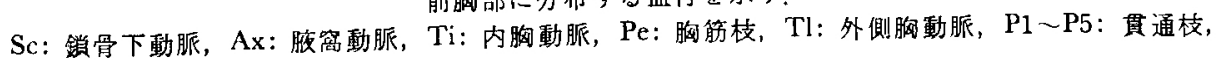
Es: 上腹壁動脈, Ia : 前胁間枝 


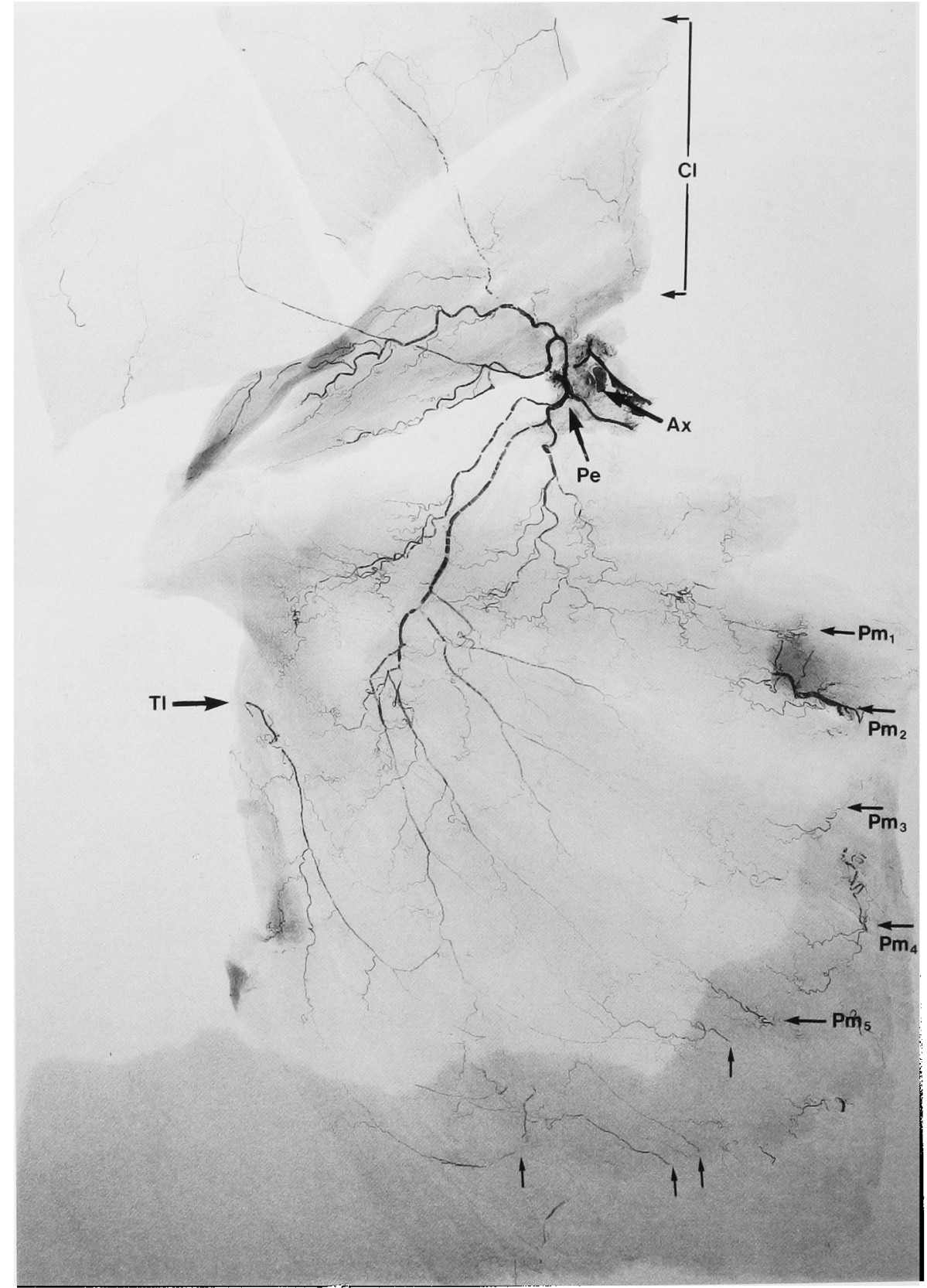

写真 8 大胸筋の微小血管造影写真 (1)

Pm1 Pm5：貫通枝の筋肉枝

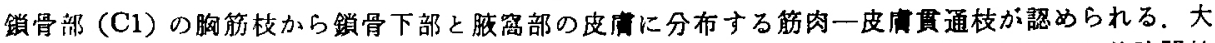

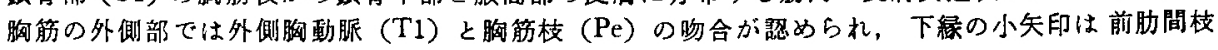
(Ia）からの買通枝を示す 


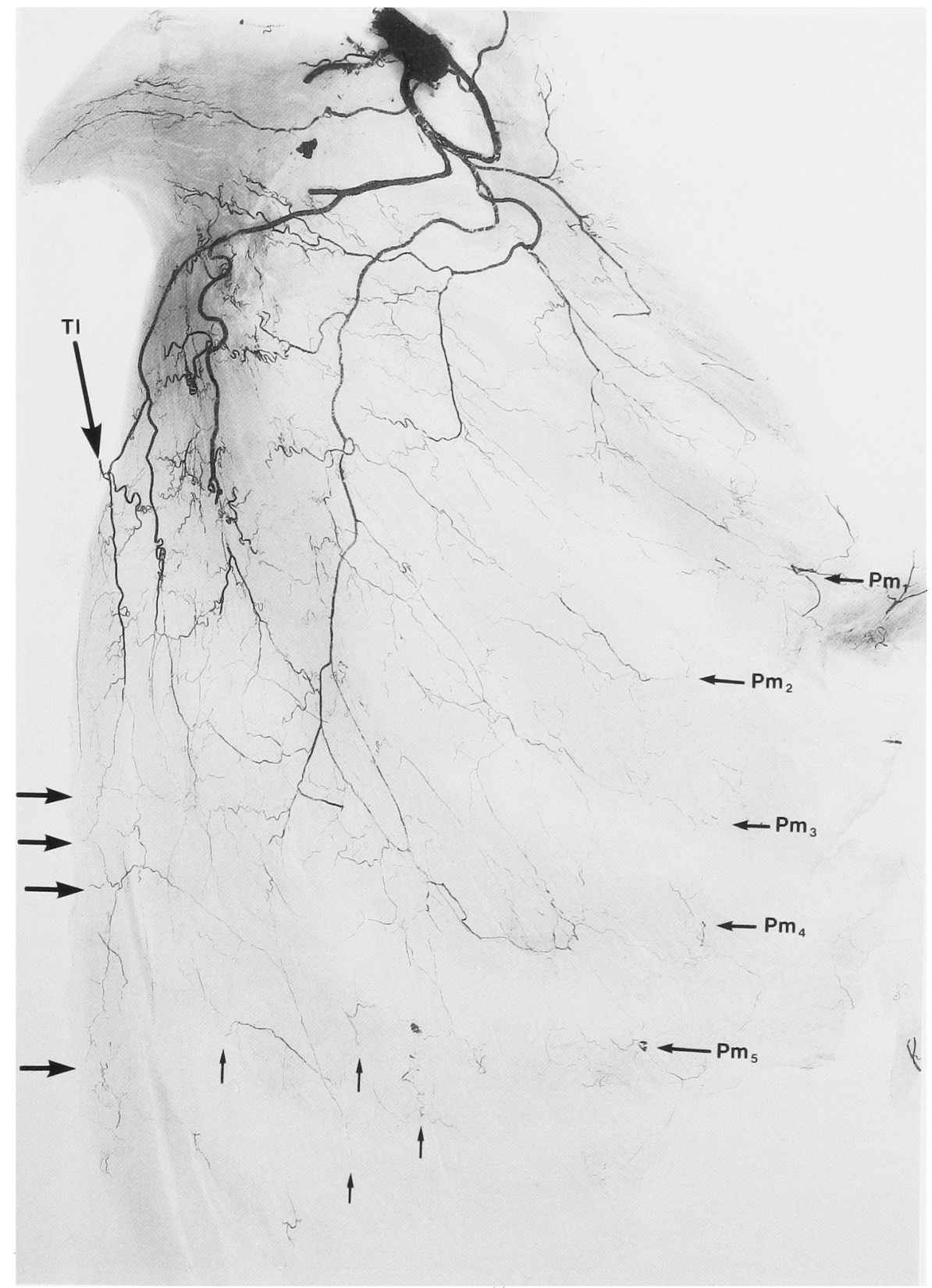

写直 9 大胸筋の铛小血管造影写真 (2) 矢印は胸筇枝 $(\mathrm{Pe})$ の外側枝が大胸節の外㑡を貫通して皮下組織層に出る枝を示す。 


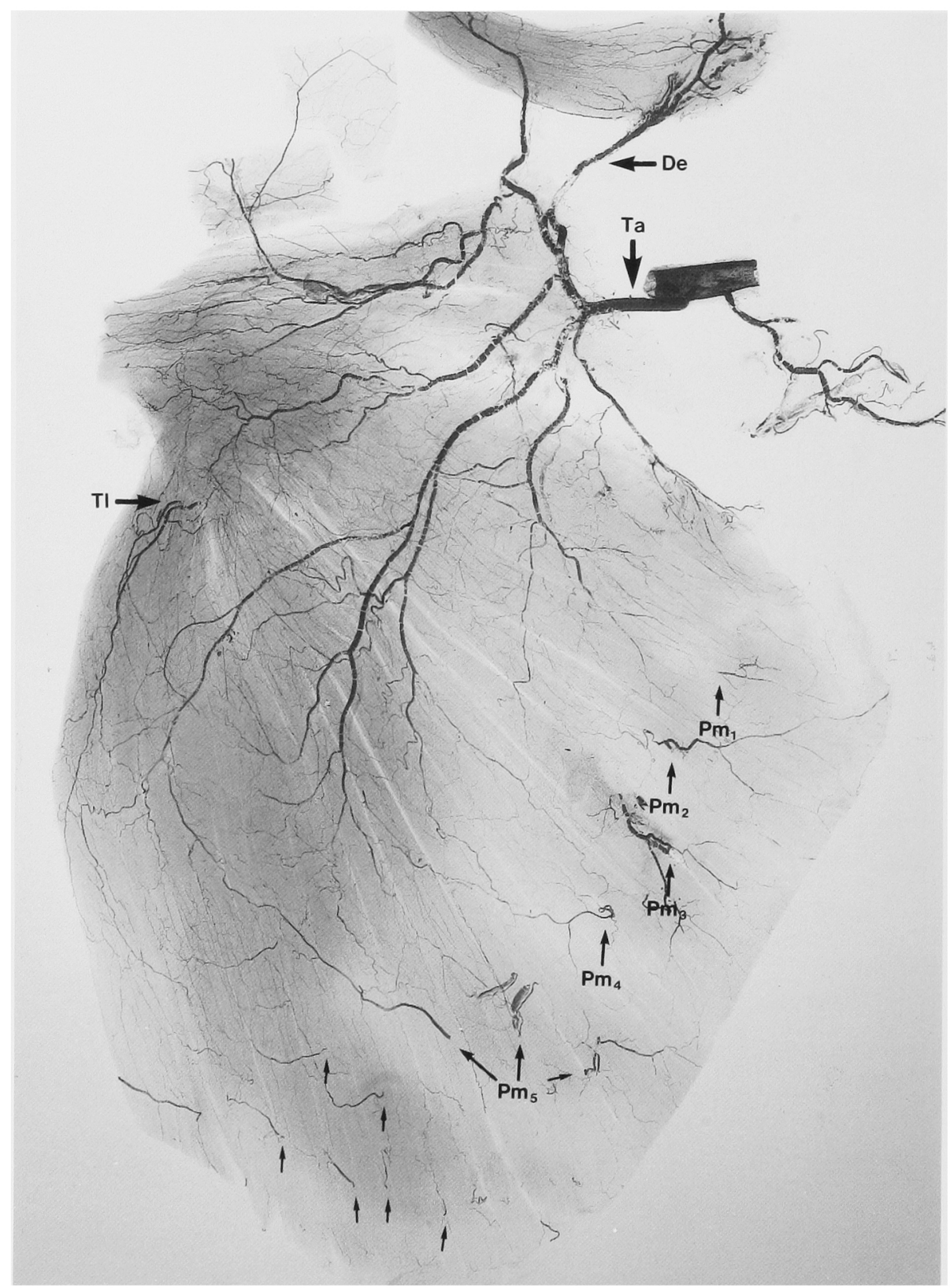

写南 10 大胸筋の微小血管造影写真(3)

$\mathrm{Ta}$ : 胸局峰動脈, De: 三角筋枝

胸筋枝 (Pe) と第 4，5肋間貫通枝の筋枝 $(\mathrm{Pm} \mathrm{4}, \operatorname{Pm} 5)$ との吻合が明璄である. 


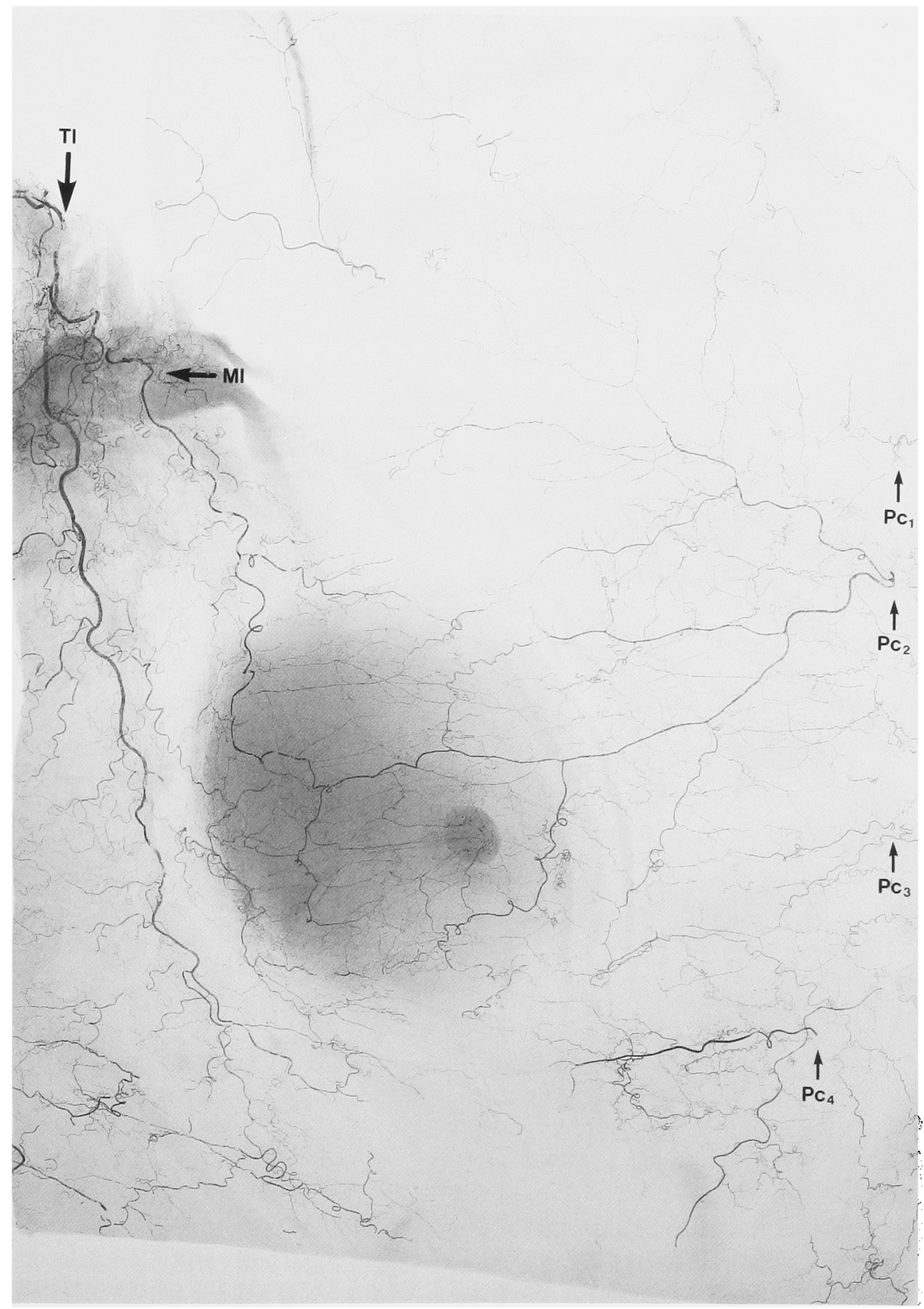

写真 11 大胸筋上の皮虚皮下組織圈の微小血管造影写真（女性）

Pc 1 Pc 4：貫通枝の皮膚枝，M 1：外側孚腺枝，第 2 肋間貫通枝の皮覻枝 (Pc 2) と，外側乳腺 枝 (M 1) が乳腺周辺の皮下組織層で吻合している。 


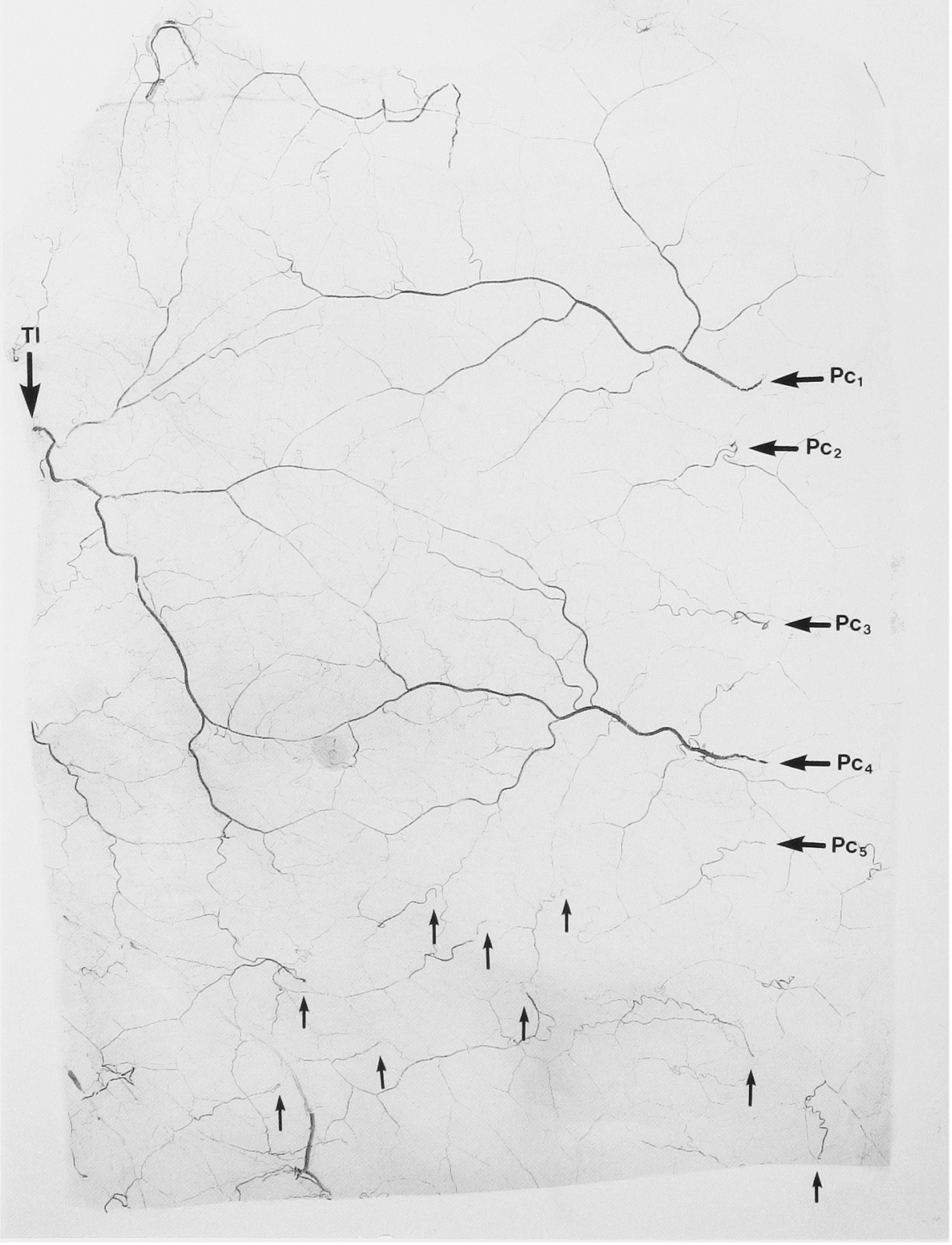

写直 12 大胸解上の皮膚皮下組緎曆の微小血管造影写真（男性） 小失印は前肋間枝 (Ia) と上腹壁動脈 (Es) からの貫通枝を示す。 


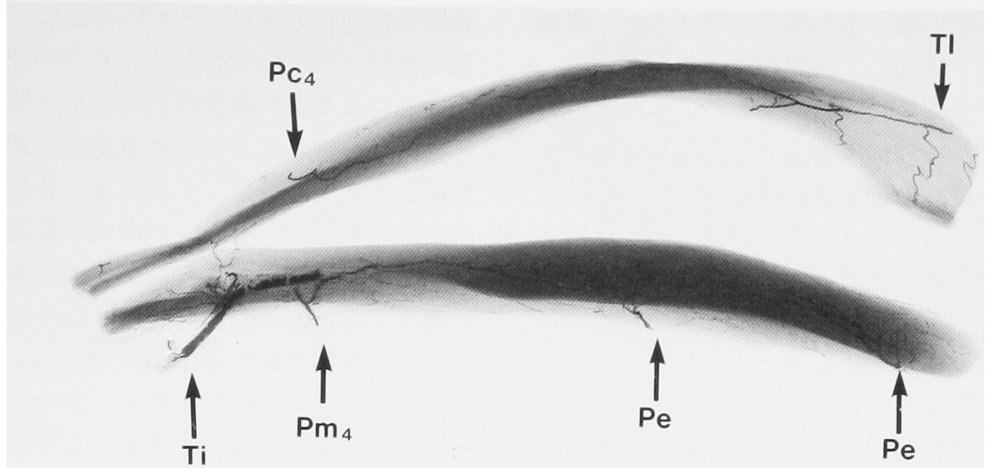

写直 $13 \mathrm{a}$ 第 4 肋間部における大胸筋（下）と皮下組織皤（上）の断面微 小血管造影写真

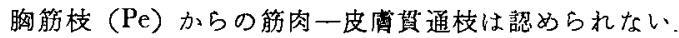

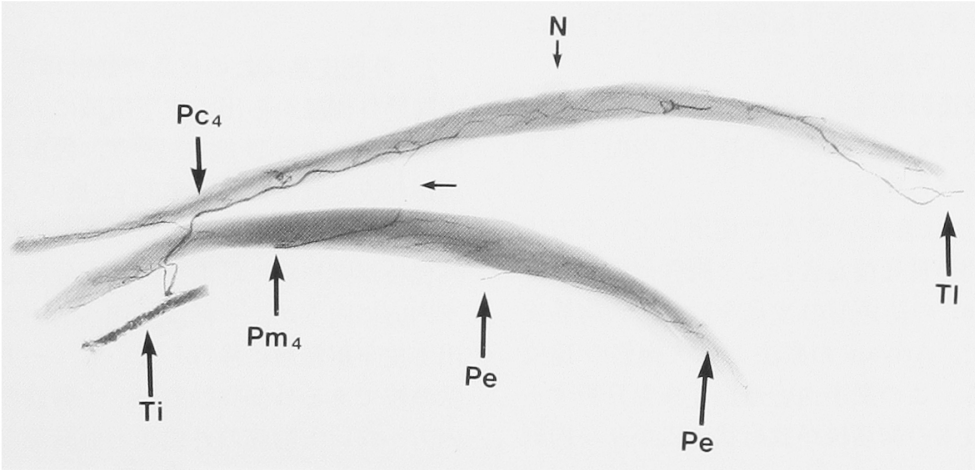

写真 $13 \mathbf{b}$ 写真 $13 \mathrm{a}$ 上り尾侧の断面微小血管造影写真

$\mathrm{N}$ : 乳頭，小矢印で示した第 4 助間貫通校の筋枝 (Pm 4) からの枝と同皮底 枝 (Pc 4) が大胸筋を貫通して皮下組織層に入る。

沿って樹枝状あるいは螺捉状に外側へ広がり，大胸胘内 で胸肩峰動脈の胸筋枝之吻合している。 また大胸筋下縁 にあたる第 5 ，第 6 助軟骨起始部には，小矢印で示した 前肋間枝から立ち上がり肋間筋を貫通して大胸筋下より 入る貫通枝があり，隣接する貫通枝ならびに胸筋枝之吻 合している（写直 $8,9 ， 10$ ）.

大胸筋上の皮庶皮下組織層の血管造影所見: 切除検体

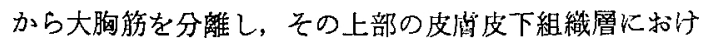
る血行形態を徽小血管造影写真から観察した。大胸筋上 の皮鹤には，胸骨外側縁の第 1 から第 5 肋間より出現し てきた内胸動脈の貫通枝（Pc 1 Pc 5) が分布し，第 2 之第 4 肋間からの貫通枝が比較的優位な検体が多かっ た. 特に女性では第 2 肋間貫通枝が三角筋方向へ向ら枝 之乳腺方向一向5乳腺枝に分れ，外側胸動脈の外側乳腺 枝と乳腺下で吻合する（写真 11）。第 4 肋間貫通枝は肋 骨の走行に沿ら上5に外側に向い，大胸觔の外倒縁付近 で外側胸動脈と吻合する。第 5 , 第 6 肋軟骨起始部の皮 膚には小矢印で示した前肋間枝ならびに上腹壁動脈から 立ち上がってきた貫通枝が分布し，これらが皮下組織層
で樹枝状に分枝しながら吻合を繰り返し皮下血管網を形 成している (写真 12).

第 4 肋間部の大胸筋 と皮有皮下組織の断面の血管造影 所見内側皮島を持つ大胸筋皮升に含をれる，第 4 肋間 部の大胸筋から皮简㐬での断面を微小血管造影写真から 分析すると前述の血行形態が立体的に表される．筋肉血 行は 2 本の胸筋枝が大胸筋の外侧下面から人り樹枝状に 分枝しながら内側に向って走行している，内側からは籍 4 肋間貫通枝の筋枝が内胸動脈上り分枝し，胸能力问 へ向ら枝と外側へ向ら枝に分れ，外側へ向ら枝は胸觔校 と筋体中央部の筋肉内で圽合している。この部分では Freeman $5^{10)}$ が主張した胸筋枝から大胸筋の筋膜を崱 通して皮下組織層へ達する筋肉一皮们貫通枝は，大胸解 表面には汪とんど認められない（写真13a）。

皮络血行は，内側加比較的太心籍 4 鿓通枝の皮的校

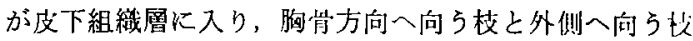
とに分れる，外側からは外側胸動脈が皮下組 織層に入 り，おのおの真皮下血管絧への細枝を出しながら筋肉酳 に平行に走行し，乳頭下周辺の皮下組織層で互に吻合し 
皮下血管網を形成している，小矢印で示すように，貴通

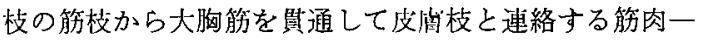
艾们買通枝が筋体中央部以 1 本認められる（写真 13b）.

解剖所見：大胸筋から笳膜を蕡通して皮下組緎層に入 る血管が出現する部位を解剖学的に観察すると, 微小血 管造影写真でも確認されたよ5に大胸筋鎖骨·部には胸筇 枝加ら直接分枝した筋肉一皮等通枝が，鎖骨部周辺の 㬳束間から出て鎖学下部から腋售部の皮下組織に分布し ている、これは色素注入法の染色域とも一致している。 大胸筋胸䏚部では，胸感起始部付近の第 1 肋間から第 5 肋間より出現する内胸動脈の貫通枝が多数観察され，第 5 , 籍 6 肋軟骨起始部には前肋間枝の賁通枝が肋岸の走 行に沿って出現し，腹值笳上では浅腹壁動脈からの貫通 枝が観察された，大胸筋の外側縁には胸筋枝の終末枝と 前胁間枝からの貫通枝が観察された。しかし大胸筋の筋 体部表面には筋膜を貫通して皮下組織層に入る近管はほ とえど諗められない（写真 14）。

大胸筋皮弁の血管造影所見：一般に多く用いられてい る 2 㮔類の大胸筋皮升を゙, 屍体上で作成しその血行形態 を微小血管造影写真から検討した。

1. 内側皮島；本法は著者が好しで使用している方法 で，第 4 ，第 5 肋間の賀通枝を含さよ5胸骨側縁から外 下方に向ら $10 \times 5 \mathrm{~cm}$ の紡錘形の皮島を設計し大胸能皮 弁を举上する方法で, Ariyan の原法より大胸筋の遠位 側に皮島が位壃する。この微小血管造影写真を分析する と，筋肉茎部には数本の胸筋枝が放射状に広がり，肉胸

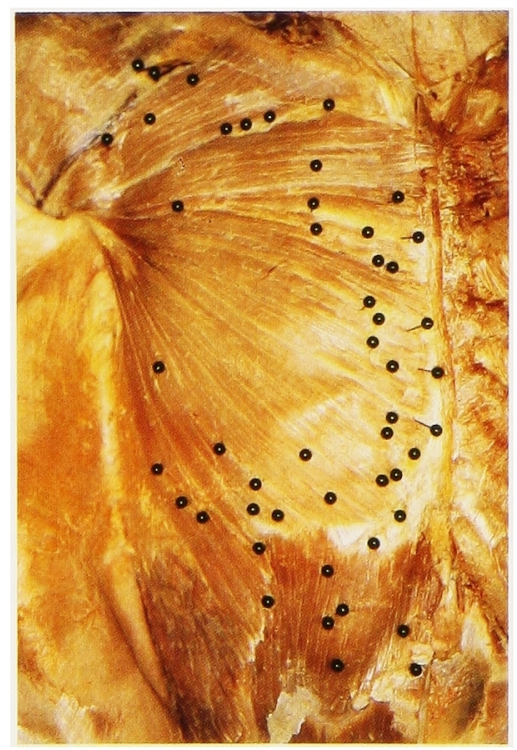

写直 14 解剖所見

大移臘を瓄通して皮下組織層に入る血管 の分布を示す。大胸管中央部には汪とん どみられず筋肉辺緑部に多い

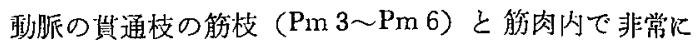
細い血管レベルで易合しているのが認められる，皮島を 平面的に見ると貫通枝の筋枝と皮消枝が重複しているた め豊富な血行があるよ5に見える（写真 15a），そこで 皮島を筋肉から分離してみると，外側へ向う皮膚枝が皮 島全体にみられ，その分布様式は貫通部から直接入る血 管と筋枝から分枝して入る血管とがあり，これらが将合 し合って皮下盘管網を形成しているのが㤎められる。 た呫島の外侧下縁には小矢印で示したような前肋間枝か ら望ち上がった貫通枝があり，この文下血管种と交通し ているため良好な血行分布を示しているとい方る(写直 15b). しかし，管皮升全体の血行形態を見ると，策堒 欰管から皮阊に至るまでの連続した循環経路は確保され ているものの, 支島は栄養血管の直接的な支配領域には なく，複数の隣接血管との吻合を介した間接的な支配関 係にある。

2. 外側皮島; この皮島の設計は，胸筋枝の終末枝が 大胸筋外側縁加出て皮下組織化入る筋肉一皮皆貫通枝 に依存する血行形態であり，乳房下部から側胸部に皮 島が作成されるため審美的に良いとされている方法で ある ${ }^{18)} こ の$ 微小血管造影写真を分析すると，胸筋枝の 外侧枝が蜥旋状に筋肉への枝を分枝しながらほとんどは

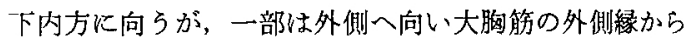
出て皮下組織層に移行している，一方側胸部には腋窝動 脈の枝である外側胸動脈が，大胸筋の停止部下面から下 内方へ向い大胸筋の外側縁と側胸部の皮下組織層に分布 し，また大胸妫の外側下縁には，小矢印で示した前肋間 枝の賃通枝が肳間筇を貫通して皮下組織穈で樹枝状に広 がり，互に牥合し密な皮下血管網を形成している。文胸 筋の外側緣から出た枝は，中矢印で示した部分ですぐに これらと吻合し側胸部の皮下血管網と連絡する血行形態 をとっている，皮島はこの皮下血管網上に作成されるた め，血行的には連続した循環経路が確保されることにな るが，内側皮島同様に学盖血管の直接的な支配領域には なく，複数の隣接血管との吻合を介した間接的な支配関 係にある（写真 16）.

考

察

筋肉子皮成を同時に移植する複合皮弁の応用は，1955 年 Owens ${ }^{23}$ が胸鎖乳突筋皮升を用いた頃から考学られて いたが，まだ筋肉と皮間の血行関係については明らか にされていなかった。皮弁血行については1973年 McGregor $5^{19)}$ ， その血行形態から axial pattern flap $と$ random pattern flap に分類したことから急速に進歩し， さらに詳細な血管解剖の結果，矨肉と皮阊の間には種々 なタイプの血行形態が存在することが解明され，1977年 McCraw ら ${ }^{20)} に よ り$ 筋皮弁の血行概念は確立されたと いえる、そして，これまで平面的であった McGregor 


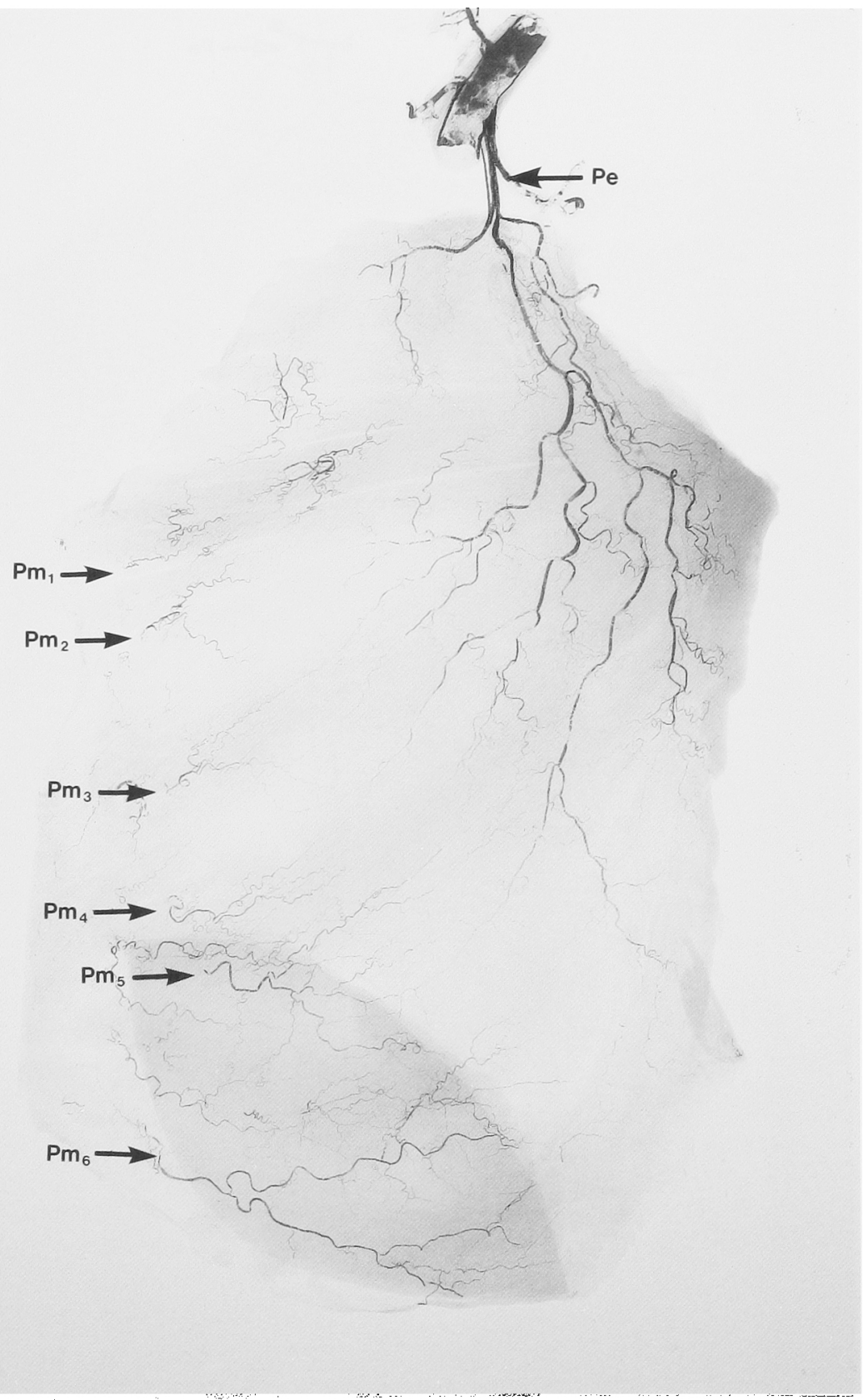

写真 $15 \mathrm{a}$ 内側皮島を付け大大胸筋皮弁の微小血管造影写真 皮島部には胸笳枝（Pe）から連続する豊富な血行が存在するようにみえる。 


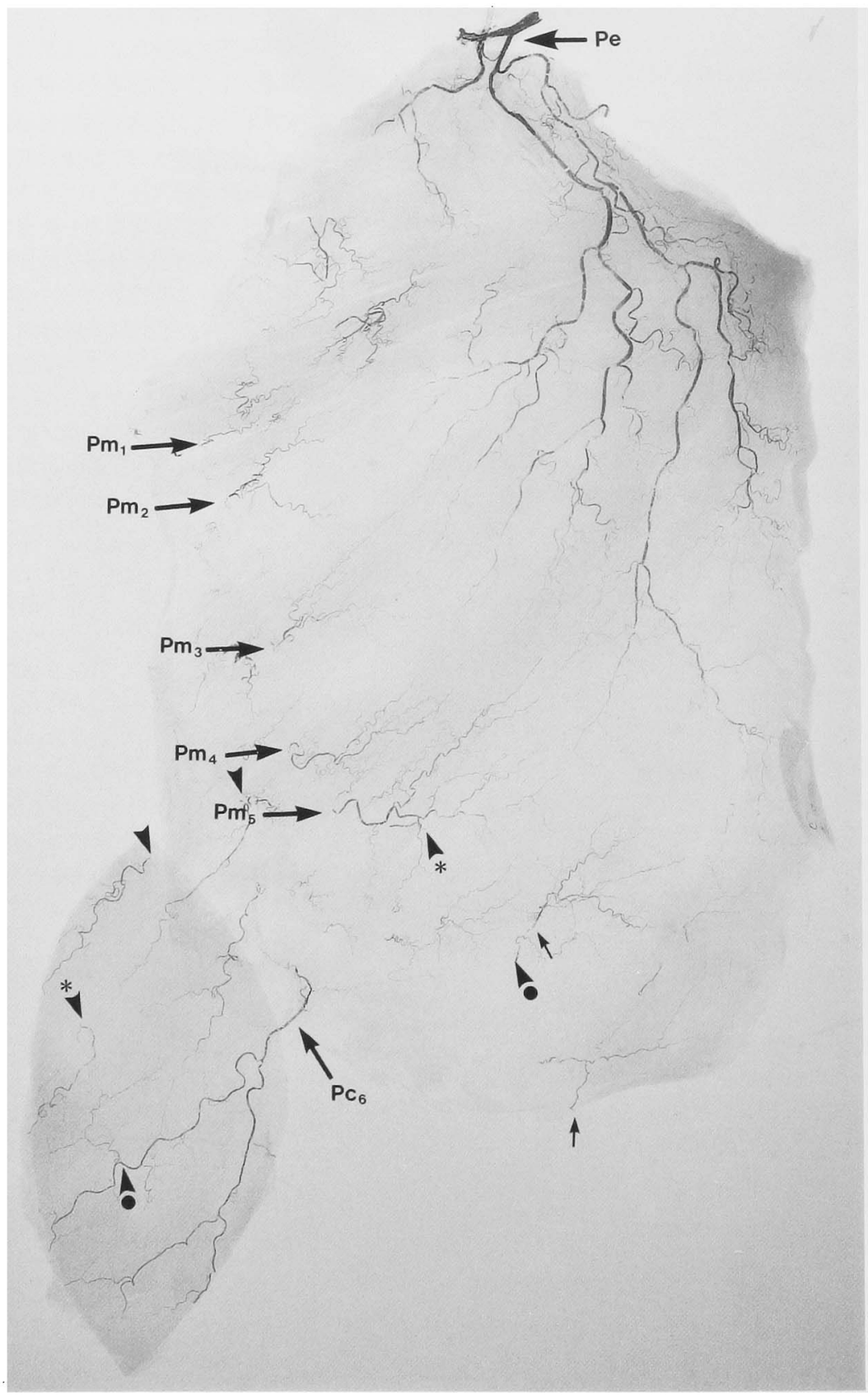

写真 $15 \mathbf{b}$ 内側皮島を分離した微小血管造影写真

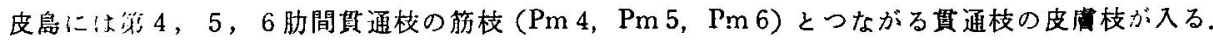

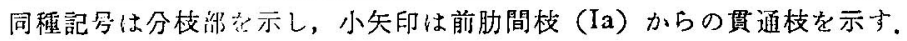




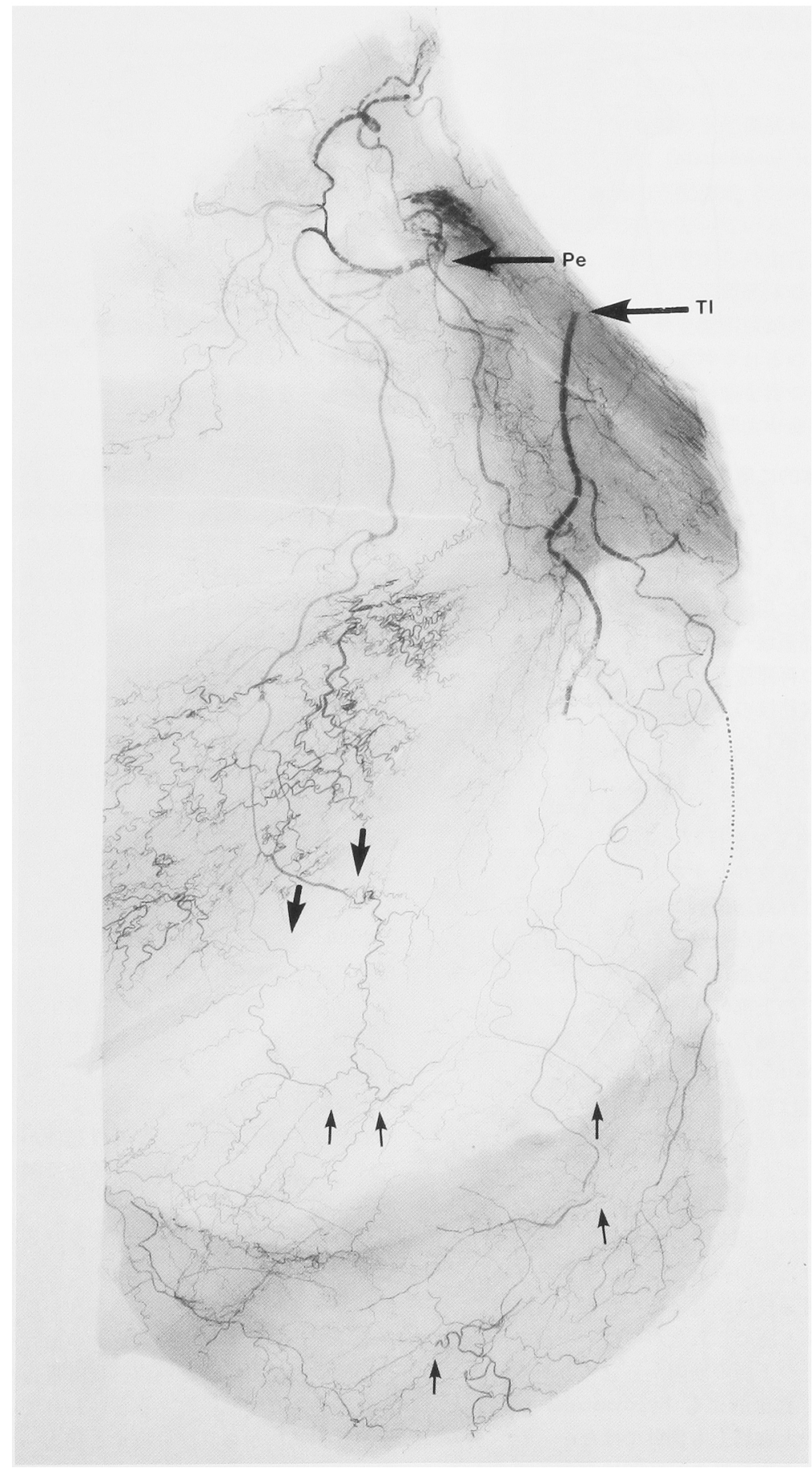

写真 16 外側皮島を付けた大胸筋皮弃の㑔小血管造影写真 小矢印は前助間枝（Ia）からの貫通枝を示し，中矢印は胸筋枝（Pe）の外側枝が大胸能を貫通して その貫通枝との肳合部を示す，点線は外側胸動脈（TI）が連結していることを示す。 

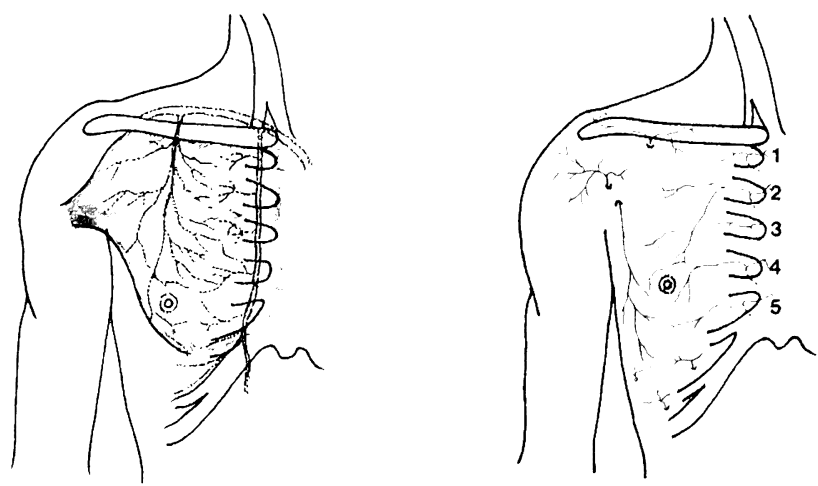

图 1 左: 大胸筋の血行を示す.

右：大胸筋上の皮虚血行を示寸。

らの血行概念を立体的に解釈することにより，筋皮并の 血行も説明できるよらになった

大胸筋は最初筋弁として胸壁の再建に用いられていた が，1968年 Hueston $ら^{23)}$ により筋肉，皮府複合皮升と して胸骨欠損の再建に用いられるよらになった，大胸笳 皮弁としての頭頸部領域への応用は，1979年 Ariyan ${ }^{5)}$ が悪性腫場切除後の再建法として初めて報告した。その 方法は胸局峰動脈胸笳枝の走行に沿って大胸筋とその上 部の皮㢈を全層で移植したため，皮原筋肉茥を有する形 態となり筋皮弁全体が厚くなり扱いにくいものであっ た. 1980年 Theogaraj ら ${ }^{24)}$ ならび Ariyan ${ }^{9}$ 自身もそ の点を改良し, 筋肉事を血行の carrier と考光, その上 に皮島を付けた島状筋皮升とする方法を報告してから， 各種の皮泉が設計され到達距離が向上し適応䉏明が搪大 した，本皮我が多くの利点を有することから臨床応用が 先行し，その基盤となる血行に闒する研究は少なく，多 くの報告が筋肉とその上部の皮们の伹行を平面的にとら えたため, 朌肉内を長軸方向に走行する栄祸血管に值接 支持された axial pattern flap と考えていた。つまり大 胸筋皮弁の血行形態は筋肉内の栄福血管から立ち上がり

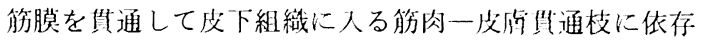
するとされてきたのである。

今回の研究の結果, 大胸筋の主要佔管である胸筋枝の

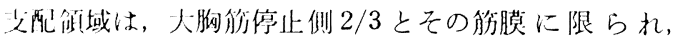
Kaplan ${ }^{16)}$ や Palmer $5^{25}$ ) の郝告と同様に直接皮下組織尿 に入る笳肉一皮涪異通枝は鎖骨下部に存在するだけで，

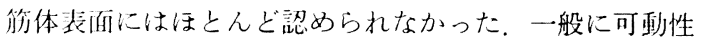
の莴い, 皮行には，その下層の筋肉から立ち上がる筋肉一

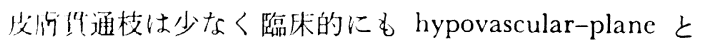
して知られており ${ }^{26)}$ 大胸筋上も例外ではなかった。一方 朌肉の起始部には, 内胸動脈や前胁問枝の貝通枝から分 枝した筋枝が，大胸筋の補助血管として多数存在し，そ の支配領域は大胸等起始侧 $1 / 3$ とその筋膜であった。 の上うに大胸筋は複数の支配片行を持つ筋肉であるが，
これらの血管同士は筋肉内あるいは筋膜層の微小血管レ ベルで吻合し，連続した循環経路を構成しているのであ る.したがって筋弁として挙上寸ると, 補助血管からの 血行が遮断され胸筋枝から貫通枝へ向ら方向性のある安 定した血行に支持されたものとなりえる．

皮盾血行に関しては，1930年代に Salmon ${ }^{27) か ゙ ェ ッ ク ~}$ 又線を使った血管造影所見から皮㡂血行の支配領域を報 告して以来，いろいろな方法で検討されてきたが，いず れの結果も大胸筋上の皮消支配血管は, 内胸動脈之前肋 閒枝から立ち上がる貫通枝の皮后枝であるとし ${ }^{13,25,26)}$, 藷者も色素注入法と血管造影法の結果から同様の所見を 得た。さらにこれらの買通枝は, 大胸筋外侧の側胸部に 分布する外侧胸動脈と吻合することにより，皮下血管網 を形成し公く前胸部全体に分布している。少藤ら ${ }^{28)}$ ( ormack ら ${ }^{18)}$ は, 胸朌枝の枝の一部が大胸㘯の外侧縁か ら出て皮下組織層に分布するとしているが, 著者が解剖 した日本人の大胸朌20検体では微小な血管が多く，それ 门体の支配领域は狄くあまり確実な血行とはいえないと 䍐われた，以上の絬果をまとめて大胸朌とその上部の皮 下組織層における血行分布をンェーマに示寸と图1のよ らになり，筋肉皮婂雨支配の貫通枝が両組織間の血行を 速続したものとするために車要な役割を果しているのが 解る(図 1 ).

このように異なる抯行支配を受ける組繊を被合皮办と して举上するためには, 筋肉内にある策養血管から皮島 にいたる連続した血行経路の存在が証明されなければな らない29)これまで大胸筋皮弁の血行形態は, 筋肉内の 胸勄枝から立ち上がる筋肉一皮鸭貫通枝が皮島を支持す る直接的な支配関係にあるといわれていたが，今回の結

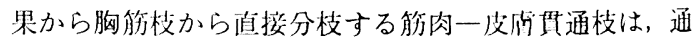
常皮息が設計される部位には存在しないことが判明し た。皮島の設計位置に関しては, 主要血管の侵入部を中 心にひろがる領域に限るとする意見 ${ }^{30)}$, 皮島の $2 / 3$ は大 胸筋上飞設計するという意見 ${ }^{16)}$ ，第 8 肋骨上までとする 


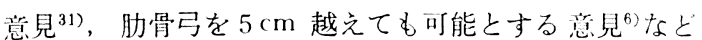
がある。しかしその血行形態に関する裏付けは述ぐられ ておらず，著者らも初期は、Ariyan の原法に従い皮島を 設計していたが，到達距離が不足しやすく祭張なく口腔 内外への移動, 縫合が困難なため, 現在では筋肉一皮原 間の血行の連続性と方向性を考虙し，貫通枝を可及的に 多く含めるよ5に第 4 肋間から第 5 , 第 6 肋軟骨付存部 に沿って三日月状の設計をすることが多い.32).

臨床応用されている皮島設計が，血行形態的に安全か つ合理的なものであるか検証するため，実験的に 2 種類

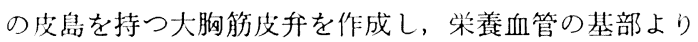
内側皮島までの血行を平面像から分析した。筇肉茥内を 長軸方向に走行する胸朌枝は第 3 ，第 4 ，第 5 肋間より 立ち上がってきた貫通枝の筋枝と吻台寸ることにより胸 筋枝が直接皮島に達しているよ5に見える。ささらにての 上部の皮膚枝が重なるため，いかにも皮島内に豊富な血 行が存在するよらにみえるが，央際には筋肉茥部の血行 支配と皮島部の血行支配は異なり，貫通枝の笳枝を介し て立体的に拉大した血行形態なのである。従来はこの部 分に対する立体的な観察がなされていなかったように思 われる，立体的に血行を観察するために作成した第 4 肋 間部の断面像から，胸筋枝と吻台した笳枝の走行を中枢 側に追ってみると, 途中で筋肉を貫通して皮下組織層に 入る枝を出しながら大胸筋下で貫通枝の主幹部に連絡寸 る。ささらにそこから立ち上がる皮留枝が皮下組織層を外 側へ向って走行し外側胸動脈之吻合することにより大胸 筋上の皮下組織層全体に分布する形態を示している。し たがって血行形態的には栄養血管から皮島に至る血行の 連続性を維持すれば，血行支配の異なる筋肉と皮间を一 本の柴養血管だけで，筋皮弁全体に血行を供給すること が可能となる。

以上の結果を踏まえて内側皮島を付けた大胸筋皮弁の 血行形態を定義すると, axial pattern を示す栄養血管 の支配領域から吻合を介して,隣接する方向性 (axiality) を持つ筋肉皮阅血行の支配領域へ連続することにより立 体的に㹡大した extended axial pattern flap といらこ とができる。

外側皮島においては胸筋枝の枝が直接皮下組織層に分 布することもあるが，ての支配領域は狭くそれたけでは 十分に皮島全体を栄養することができない，しかし外側 胸動脈のような方向性のある血管と吻合することにより 支配領域は拡大し皮泉を作成することが可能となる。し たかって血行形態的には内侧皮皇と同様に extended axial pattern flap ということができる.

extended axial pattern flap の概念は皮弁を延長する 方法として考えられたもので, 西條 ${ }^{22)}$ は, axial pattern の先端に random pattern の領域を length to breadth ratio の原則 ${ }^{19)}$ に従って延長した血行形態と, axial pattern の領域から隣接する複数の axial pattern の領域
一延長した血行形態があるとしている，往来，この概念 は皮弁に対するもので筋皮升には適用されていなかった が，後者の血行形態を立体的に解釈することにより，大 胸筋皮升の血行形態を extended axial pattern と考古た ほらが理解しやすいと思われる。

また大胸筋皮弁を血管の支配領域からみると，栄養血 管の解剖学的支配領域 (anatomical territory) から吻合 を介して拡大する動的支配領域 (dynamic territory) 内 に皮島が存在する形態をとっている。つまり筋皮弁とし て挙上されると, 補助血管からの血行が遮断されるため 王平衡が変化し，連続した循環経路の中では一定方向の IIII流が生じ，栄等血管の支配領域がダイナミックに拉大 するため皮息への血行が維持されるのである．

このような安定した血行形態を持つ筋皮升に，皮島の 部分壊死や辺縁壊死が生じる理由を血行形態から検討す ると, 以下の要因が考えられる。

\section{1. 笳肉血行に対する外科的侵襲}

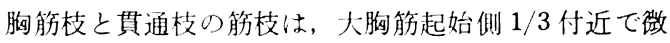
小血管レベルで吻合しているため,この周辺の筋肉に対 する非愛護的手術操作は血管の損傷や血管の䳌縮を引き 起こす。また筋肉茥部の王迫も皮島部への血行不全を招 く可能性がある.

\section{2. 貫通枝主幹部の処理の誤り}

筋肉血行と皮伯血行を連続した循環経路として確保す るためには，両者を連絡する貫通枝の主幹部を大胸筋下 で基部まで追い結禁処理して䇗皮弁に含めるようにする 必要がある ${ }^{33)} こ の$ 処理を䛊ると皮島部に部分的な血行 不全を起こす。この方法は，DP 皮弁における三角筋大 胸筋溝での三角等枝の処理法 ${ }^{34)}$ と同様の考方方である.

\section{3. 皮島設計の誤り}

皮島に含める貝通枝の数を多くするように設計するこ とは，血行上の安全性を高める。また貫通枝の皮䖉枝が 皮下組織層でどのような分布を示しているか，その方向 性を認識した上で設計する必要がある。皮阎血行の方向 性を無視して皮島を設計すると，その支配領域を越えた 部分の血行は低下し辺縁壊死の原因となる。 Weaver $5^{35)}$ p Sharzaer $5^{36)}$ の皮自設計は, この原則を守って いるため, 安全で合理的なものと思われる。

\section{4. 筋膜処理の誤り}

大胸笳表面の筋膜の血行は，笳肉血行と皮盾血行の両 者から支配を受けているため，筋膜を温存することは皮 島部への補助的血行として重要である。また胳膜は皮島 を筋肉茥に接着させる働きもあるため，微小血管に支持 される皮店血行を保護する意味からも注意して処理する 必要がある。

\section{5. 血管の変異}

胸筋枝の偏位は少ないが，大胸筋外側縁での胸筋枝か ら出る筋肉一皮虚貫通枝の存在は不確実であり注意が必 要である。外側皮島を作成する際には，外側胸動脈を含 
めるようにすると血行的には安全性が高まる。

\section{結語}

15体の新鮮屁体を用いた色素注入法と血管造影法なら びにその解剖所見から，大胸筋皮并の血行形態を検討し 以下の所見を得た。

1。色素注入法の結果，大胸筋とその上部の皮何には それぞれ異なる血行支配が存在した。

2。大胸筋皮弁の栄荃血管である胸肩峰動脈胸朌枝の 支配領域は，大胸筋の停止側 $2 / 3$ とその筋膜，ならびに 鎖骨下部之側胸部の皮䖑に限られ，大胸筋表面には直接 胸筋枝から立ち上がる筋肉一皮原貫通枝は認められなか った。

3。内胸動脈貫通枝の支配領域は，大胸笳起始側 $1 / 3$ とその筋膜ならびに前胸部皮原のほほ全域に及び，皮下 組織層にて外側胸動脈之前胁間枝の貫通枝之の吻合を認 めた。

4. 胸筋枝が大胸筋内で貫通枝の筋枝と徽小血管レべ ルで吻合し，さらに貝通枝の主幹部を介して皮店枝に至 る連続した循環経路を形成寸ることにより，大胸筋皮并 の血行が維持される.

5 。大胸筋皮弁の血行形態は，胸筋枝の直接的支配で はなく複数の隣接血管との吻合を介して立体的に昖大し た， extended axial pattern flap といらことができる。

6。少胸筋皮弁の部分壊死や辺縁壞死の原因を血行形 態の観点から検討する之，血管の分布様式や支配領域な らびに血管解剖を正しく認識することによりその危除性 を低下させることが可能と思われた。

稿老終えるにあたり，終始ご䇱篤なるこ指尊とご恔閲 を睗わりました横浜市立大学医学部口腔外科学諈坐藤田 浄秀教授に深厚なる感謝の意を表しま子。また本研究を 進めるにあたり終始こ教示を賜わりました本学形成外科 学教室西條正城科長に的意を表します。さらに虫重なる こ献体を提供していたたきました本学第 1 解剖学满座澤 田元教授ð始めとする諸先生方に心から感谢いたしま 寸。最後にこ献体下さったこ遗体に対し感韵与るととも

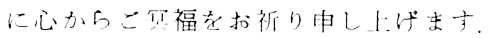

\section{引用 文 献}

1) 波利北消紀, 山田故, 他 Myocutancous flap の理論と応用。形成外科 22: 664-679 1979 .

2) Owens, N.A. A compound neck pedicle designed for the repair of massive facial defect; formation, development, and application. Plast Reconstr Surg 15: 369-389 1955.

3) Quillen, C.G., Shearin, J.C., et al.: Use of the latissimus dorsi myocutaneous island flap for reconstruction in the head and neck area. Plast Reconstr Surg 62: 113-117 1978.

4) McCraw, J.B., Maree, W.P., et al.. Uses of the trapezius and sternomastoid myocutaneous flaps in head and neck reconstruction. Plast Reconstr Surg 63: 49-57 1979.

5) Ariyan, S.: The pectoralis major myocutaneous flap, A versatile flap for reconstruction in the head and neck. Past Reconstr Surg 63: 73811979

6）坂束正士：大胸筋支利用した頭頚部の再建法. 手術 34：751-761 1980.

7) 工藤啓吾, 拓殖信夫, 他：大胸朌皮弁による口 腔㾔切除後の即時再建。日口外誌 29：514-521 1983.

8) Baek, S., Lawson, W., et al.. An analysis of pectoralis major myocutaneous flaps. Plast Reconstr Surg 69: 460-467 1982.

9) Ariyan, S.: Further experiences with pectoralis major myocutaneous flap for the immediate repair of defects from excisions of head and neck cancers. Plast Reconstr Surg 64: 605-612 1979.

10) Freeman, J.L., Walker, J.S.P., et al.: The vascular anatomy of the pectoral major myocutaneous flap. $\mathrm{Br}$ J Plast Surg 34: 3-10 1981.

11) Mehrhof Jr., A.I., Rosenstock, A., et al.: The pectoralis major myocutaneous flap in head and neck reconstruction. Am J Surg 146: 478-482 1983.

12）波利井清紀, 谷太三郎：筋升扣よび笳皮升一 一乙の臨床応用之遠隔成績—医学教育出版, 東京, 1985，43-53面。

13) Nakajima, H., Maruyama, Y., et al.: The definition of vascular skin territories with prostaglandin $\mathrm{E}_{1}$ - the anteriorchest, abdomen and thigh-inguinal region. $\mathrm{Br} \mathrm{J}$ Plast Surg 34: 258-263 1981.

14) Reid, C.D. and Taylor, G.I.: The vascular territory of the acromiothoracic axis. Br J Plast Surg 37: 194-212 1984.

15) 平沢 興, 岡本道雄: 解剖学 2 脈管学, 神経 系、第10版, 金原出版, 東京, 1969, 42-52頁.

16) Kaplan, I.B. and Harwick, R.D.: Pectoralis major myocutaneous island flap revisited: A sentinel vessel simplifying dissection. Head Neck Surg 5: 452-456 1983.

17) Bakanjian, V.Y.: A two-stage method for pharyngoesophageal construction with primary pectoral skin flap. Plast Reconstr Surg 36: 1731841965.

18) Cormack, G.C. and Lamberty, B.G.H.: The arterial anatomy of skin flaps. Chirchill Livingstone, London, 1986 p 410-412. 
19) McGregor, I.A. and Morgan, G.: Axial and random pattern flaps. Br J Plast Surg 26: 202-213 1973.

20) McCraw, J.B., Dibbell, D.G., et al.: Clinical definition of independent myocutaneous vascular territories. Plast Reconstr Surg 60: 341-352 1977

21）丸毛英二編：筋皮弁と管弁, 第 1 版, 克誠堂出 版, 東京, 1985, 15-40頁。

22) 西條正城：新外科学大系 29 巻 A 第 1 版, 中山 苦店, 東京, 1988, 141-159面。

23) Hueston, J.T. and McConchie, I.H. A compound pectoral flap. Aust NZJ Surg 38: 61-70 1968

24) Theogaraj, S.D. and Merritt, H., et al.: The pectoralis major musculocutaneous island flap in single-stage recostruction of the pharyngoesophageal region. Plast Reconstr Surg 65: 267-276 1980.

25) Palmer, J.H. and Taylor, G.I.: The vascular territories of the anterior chest wall. $\mathrm{Br} J$ Plast Surg 39: 287-299 1986.

26) Taylor, G.I. and Palmer, J.H.: The vascular territories angiosome of the body: experimental study and clinical application. Br J Plast Surg 40: 113-141 1987.

27）26）より引用。

28）阁藤等，佐野文彦，他.大胸解皮升の採取部
位の検討。耳喉 56：1003-1006 1984 .

29) 波利井淂紀：Muscle 扣よび Musculocutaneous flap の理諭と实際。于乪 34: 729-741 1980.

30）早津良和，復崎文彦，他：大胸筋皮弁を用いた 口腔癌切除後の即時再建. 口科誌 37: 338-344 1988.

31）锶永慎介，毛山章，他：大胸笳皮弁に上る頭

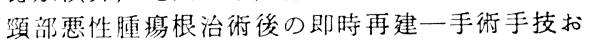
よびその街後成綂に対する検討一。形成外科 24: 122-129 1981.

32) 大村進, 石川好美, 他: 恶性腫序切除後の口 腔領域即時再建に関する検討一大胸筋皮弁に上 る40症例一。 日口处誌 $35: 79-921989$.

33）石川好美，川辺良一，他：大胸筋皮弁に関する 臨床的ならびに基礎的研究。II 色素注入法によ 万大胸解皮弁の血行形態に閔する基礎的研究と 臨床応用上の問題点(抄). 日外誌 33：261126121987.

34) 鳥居修平：舌 - 口腔の再建術. 手術 38: 37-48 1984.

35) Weaver, A.W., Vandenbreg, H.J., et al.: Modified bilobular ("Gemini") pectoralis major myocutaneous flap. Am J Surg 144: 482-488 1982

36) Sharzer, L.A., Kalisman, M., et al.: The parasternal paddle: A modification of the pectoralis major myocutaneous flap. Plast Reconstr Surg 67: 753-762 1981. 